\title{
Plasma progesterone levels during delayed implantation in the European badger (Meles meles)
}

\author{
M. Bonnin, R. Canivenc and Cl. Ribes \\ Laboratoire d'Endocrinologie Expérimentale, Faculté de Médecine, Bordeaux II, \\ Domaine de Carreire, 146 Rue Leo Saignat, 33076 Bordeaux Cedex, France
}

\begin{abstract}
Summary. There was a biphasic pattern of progesterone secretion during the year. Delayed implantation was characterized by low concentrations from February to June, a significant $(P<0.001)$ increase during July, August and September, and a return to low levels in October-November. A second significant increase $(P<0.001)$ was observed in December and early January just before the presumed time of implantation.
\end{abstract}

\section{Introduction}

In the European badger (Meles meles) a post-partum ovulation in February or March is followed by a prolonged period of delayed implantation during which the blastocysts are retained unattached within the uterine lumen. Implantation occurs in December or January (Canivenc \& Laffargue, $1956,1957)$. There is a significant correlation $(r=0 \cdot 66)$ between luteal cell size and progesterone content and measurements of luteal cell size and progesterone content (Canivenc, Short \& BonninLaffargue, 1966) suggest that the corpora lutea are inactive throughout much of the delay period (March to July), normal luteal function being resumed slowly from September to December as the time of implantation approaches. The purpose of the present study was to correlate these apparent changes in luteal activity with plasma levels of progesterone.

\section{Materials and Methods}

Blood samples were taken from the radial vein of female badgers captured at the earth throughout the year. Five females were also maintained in the laboratory and bled once a week. After centrifugation of the blood samples at $+4^{\circ} \mathrm{C}$ and $3125 \mathrm{~g}$ for $15 \mathrm{~min}$ the plasma was removed and stored at $-25^{\circ} \mathrm{C}$ until the time of analysis.

The progesterone determinations were carried out by radioimmunoassay with an antiserum to progesterone-1 1 $\alpha$-BSA, raised in sheep and selected for its titre and specificity (Scaramuzzi, Corker, Young \& Baird, 1975). The cross-reactivity measured at $50 \%$ displacement was $2 \cdot 2 \%$ for $17 \alpha$ hydroxyprogesterone, $8 \%$ for deoxycorticosterone, $1.9 \%$ for corticosterone, $1.1 \%$ for $20 a$ - and $20 \beta$-hydroxyprogesterone, and $<1 \%$ for testosterone and androstenedione. An aliquot of 0.1 or $0.2 \mathrm{ml}$ plasma was used for each assay; $4000 \mathrm{~d} / \mathrm{min}$ of $\left[1,2,6,7^{3}-\mathrm{H}\right]$ progesterone were added to estimate procedural losses and the mean recovery was $77 \cdot 7 \pm 0 \cdot 6 \%$ (s.e.m., $n=200$ ). Progesterone was extracted by 10 volumes of freshly redistilled petroleum ether (b. pt $40-60^{\circ} \mathrm{C}$ ). The aqueous phase was frozen in a mixture of methanol and solid $\mathrm{CO}_{2}$ and the ether-extractable fraction was decanted into another tube and evaporated to dryness under nitrogen at $40^{\circ} \mathrm{C}$. Assay tubes, containing unknown

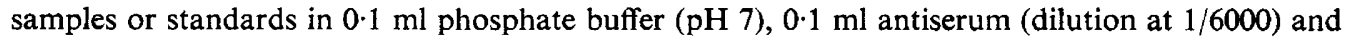
$0 \cdot 1 \mathrm{ml}\left[1,2,6,7^{3}-\mathrm{H}\right]$ progesterone $(20000 \mathrm{~d} / \mathrm{min})$ in phosphate buffer, were estimated in duplicate for samples and in triplicate for standards. The interassay precision was $11.5 \%$. The lower limit of sensitivity of the assay was $0 \cdot 2 \mathrm{ng} / \mathrm{ml}$.

All results were tested by Student's $t$ test.

\section{Results}

The results from the wild badgers revealed a biphasic pattern of progesterone secretion during the year. Delayed implantation was characterized by low levels of progesterone from February to June, a significant increase $(P<0.001)$ during July, August and September, and a return to low levels in 
Table 1. The mean \pm s.e.m. monthly plasma progesterone concentrations in wild badgers

\begin{tabular}{lcccccccccccc}
\hline $\begin{array}{c}\text { Feb. } \\
\text { and } \\
\text { March }\end{array}$ & April & May & June & July & Aug. & Sept. & Oct. & Nov. & Dec. & Jan. & Feb. \\
\hline $\begin{array}{l}\text { No. of badgers } \\
\text { Progesterone }\end{array}$ & 1.78 & 8 & 12 & 19 & 17 & 10 & 14 & 23 & 17 & 20 & 15 & 6 \\
conc. (ng/ml) & \pm 0.52 & \pm 0.30 & 2.50 & 3.13 & 5.00 & 6.51 & 6.03 & 2.45 & 2.28 & 4.20 & 9.04 & 16.90 \\
\hline
\end{tabular}

October and November (Table 1). The initiation of implantation in December and early January was correlated with a second significant increase $(P<0.001)$ in plasma progesterone levels which reached the highest mean value in February, when the animals were presumed to be pregnant.

The plasma progesterone levels of the 5 laboratory females bled at weekly intervals throughout

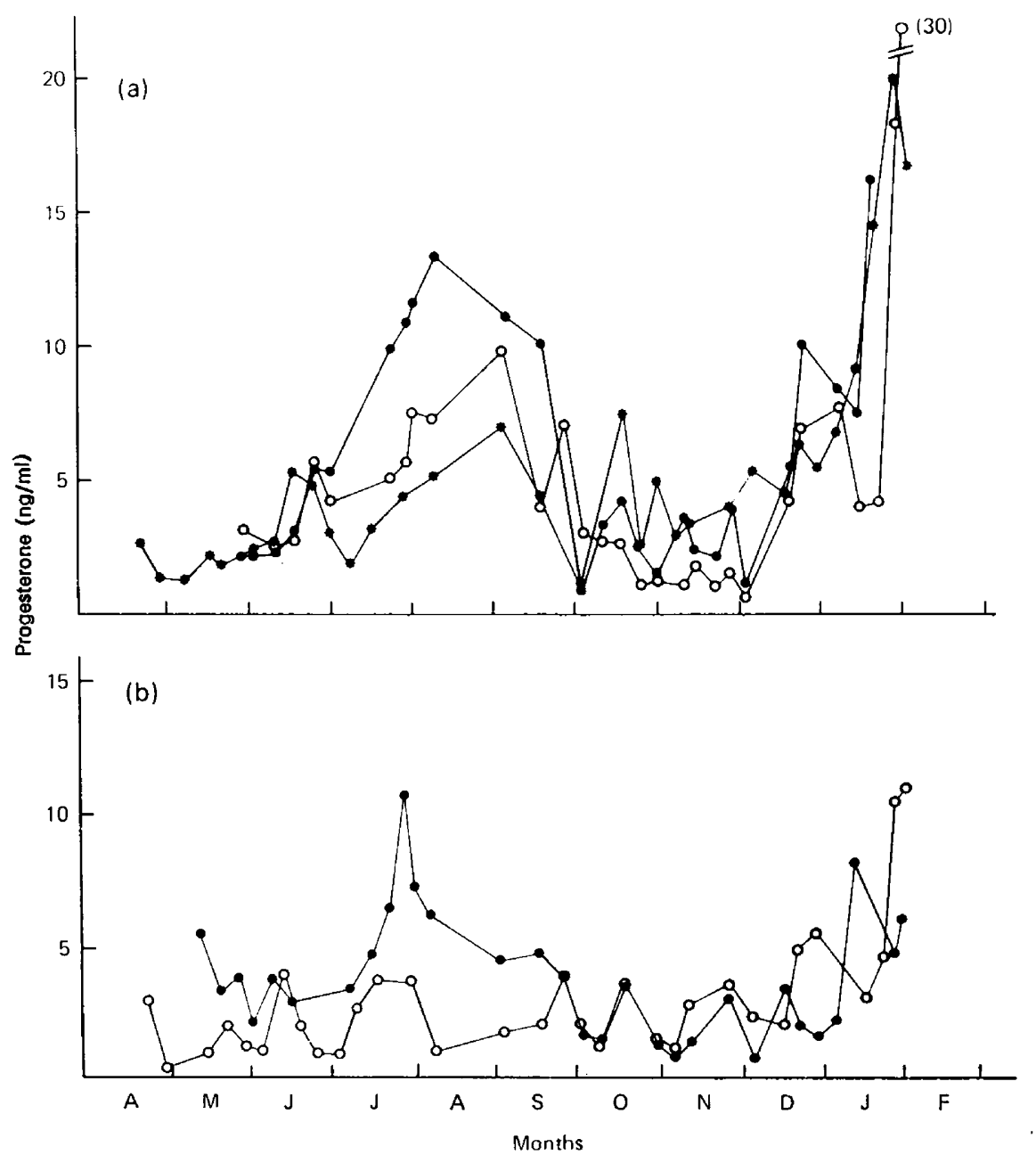

Text-fig. 1. Plasma progesterone levels in 5 laboratory female badgers bled weekly throughout the year. (a) Badgers $1(\bullet), 2(0)$ and $3(*)$ which had 6, 4 and 4 corpora lutea, respectively, and 6 blastocysts, 4 and 4 embryos in the uterus when killed on 19 January, 17 January and 2 February. (b) Badgers 4 (๑) and 5 (O) which had 2 corpora lutea each but no blastocysts or implantations in the uterus at death on 30 January and 2 February respectively. 
the year are presented in Text-fig. 1. All the animals were killed in January and February and details of the number of corpora lutea and the developmental state of the embryos, when present, were recorded. A biphasic progesterone profile was observed in Badgers 1,2 and 3 which had CL and embryos (Text-fig. 1a), and Badger 4, which had ovulated normally but did not contain blastocysts (Text-fig. 1b), but this pattern was not as clear in Badger 5.

\section{Discussion}

This study has revealed marked changes in the plasma concentration of progesterone during delayed implantation in the European badger. The low levels of progesterone observed from February to June are indicative of the lack of luteal activity at this time (Canivenc, Short \& Bonnin-Laffargue, 1966): the lowest mean values of luteal size and progesterone content were observed in May, June and July. Mid-way through the period of delay, however, a highly significant increase in plasma progesterone concentration was observed and this was sustained for a period of 3 months (July, August and September). The increase in luteal size and progesterone content observed in September (Canivenc et al., 1966) suggests an ovarian origin for this steroid. However, an extra-ovarian progesterone source, as suggested by Mead \& Eik-Nes (1969) for spotted skunk, Møller (1973) for mink and Gulamhusein \& Thawley (1974) for stoat, cannot be excluded. Whatever the origin of this progesterone it appears to exert a marked progestational influence on the uterus, because the endometrium begins to assume a secretory appearance from this time (Bonnin, 1964). During October and November the plasma concentration of progesterone returned to low levels despite the fact that luteal cell size and progesterone content remain elevated (Canivenc et al., 1966) and the uterus retains a secretory aspect (Bonnin, 1964). A second significant increase in plasma progesterone concentration was observed in December and early January just before the presumed time of implantation. The termination of diapause in such mustelids as the spotted skunk (Mead \& Eik Nes, 1969), mink (Møller, 1973) and stoat (Gulamhusein \& Thawley, 1974) is associated with a similar increase in plasma progesterone levels, reflecting the initiation of full luteal activity.

Plasma progesterone levels also increase in the armadillo, Dasypus novemcinctus, at time of implantation (Peppler \& Stone, 1976), but in roe deer, Capreolus capreolus concentrations of progesterone during the preattachment phase of embryonic elongation (Aitken, 1974) are not significantly different from those during diapause. The administration of progesterone to intact or ovariectomized badgers during the delay phase does not terminate diapause (Canivenc \& Laffargue, 1958 ) and the induction of implantation may involve more than a simple increase in ovarian progesterone production.

We are indebted to Professor R. V. Short and Dr J. Aitken for advice and criticism during the preparation of the manuscript. The antiserum was generously donated by Professor Short. This work was supported by C.N.R.S. ERA No. 699.

\section{References}

AITKEN, J. (1974) Delayed implantation in the roe deer (Capreolus capreolus) Ph.D. thesis, University of Cambridge.

BonNIN, M. (1964) Contribution à l'étude de l'histophysiologie de l'appareil génital femelle du Blaireau européen, Meles meles L. Th. D., Bordeaux.

Canivenc, R. \& Laffargue, M. (1956) Présence de blastocystes libres intra utérins au cours de la lactation chez le Blaireau européen, Meles meles L. C. $r$. Séanc. Soc. Biol. 150, 1193-1196.

Canivenc, R. \& Laffargue, M. (1957) Relation des corps jaunes et des blastocystes au cours de la nidation différée du Blaireau européen, Meles meles L. C. r. Séanc. Soc. Biol. 151, 561-564.
Canivenc, R. \& Laffargue, M. (1958) Action des différents équilibres hormonaux sur la phase de vie libre de l'oeuf fécondé chez le Blaireau européen, Meles meles L. C. r. Séanc. Soc. Biol. 152, 58-61.

Canivenc, R., Short, R.V. \& Bonnin-Laffargue, M. (1966) Etude histologique et biochimique du corps jaune du Blaireau européen, Meles meles L. Annls Endocr. 27, 401-413.

Gulamhusein, A.P. \& Thawley, A.R. (1974) Plasma progesterone levels in the stoat. J. Reprod. Fert. 36, 405-408.

MraD, R.A. \& Eik-Nes, K.B. (1969) Seasonal variations in plasma levels of progesterone in western forms of the spotted skunk.J. Reprod. Fert., Suppl. 6, 397-403. Downloaded from Bioscientifica.com at 04/26/2023 01:35:23PM 
Møller, O.M. (1973) The progesterone concentrations in the peripheral plasma of the mink (Mustela vison) during pregnancy. J. Endocr. 56, 121-132.

PePpler, R.D. \& Stone, S.C. (1976) Plasma progesterone level in the female armadillo during delayed implantation and gestation: preliminary report. Lab. Anim. Sci. 26, 501-504
SCaramuzzI, R.S., Corker, C.S., Youno, G. \& BAIRD, D.T. (1975) Production of antisera to steroid hormones in sheep. In Steroid Immunoassay, pp. 111-132. Eds E.H.D. Cameron, S.G. Hillier \& K. Griffiths. Alpha Omega Alpha, Cardiff.

Received 29 March 1977 